\title{
MODEL PEMBELAJARAN TEMATIK DENGAN \\ PENERAPAN METODE BERCAKAP-CAKAP DAN \\ BERCERITA UNTUK MENINGKATKAN PRESTASI \\ BELAJAR BAHASA INDONESIA ANAK KELAS III \\ SEMESTER I TAHUN PELAJARAN 2017/2018 \\ DI SD NEGERI 22 DANGIN PURI
}

\author{
Oleh \\ Ni Ketut Rumiati \\ SDN 22 Dangin Puri \\ niketutrimiati@gmail.com
}

\begin{abstract}
ABSTRAK
Penelitian ini dilaksanakan di SD Negeri 22 Dangin Puri di Kelas III yang kemampuan siswanya untuk mata pelajaran Bahasa Indonesia cukup rendah. Tujuan penulisan penelitian tindakan kelas ini adalah untuk mengetahui apakah model pembelajaran Tematik dengan penerapan metode bercakap-cakap dan bercerita dapat meningkatkan prestasi belajar siswa. Metode pengumpulan datanya adalah tes prestasi belajar. Metode analisis datanya adalah deskriptif. Hasil yang diperoleh dari penelitian ini adalah model pembelajaran Tematik dengan penerapan metode bercakap-cakap dan bercerita dapat meningkatkan prestasi belajar siswa. Ini terbukti dari hasil yang diperoleh pada pada awalnya 64,72. setelah diberikan tindakan pada siklus I meningkat menjadi 66,47 dan pada siklus II meningkat lagi menjadi 77,76. Kesimpulan yang diperoleh dari penelitian ini adalah pembelajaran Tematik dengan penerapan metode bercakap-cakap dan bercerita dapat meningkatkan prestasi belajar Bahasa Indonesia siswa kelas III semester I Tahun Pelajaran 2017/2018 SD Negeri 22 Dangin Puri
\end{abstract}

\section{Kata kunci: Pembelajaran Tematik, Metode Bercakap-Cakap Dan} Bercerita, Prestasi Belajar, Bahasa Indonesia

\section{PENDAHULUAN}

Guru merupakan ujung tombak pendidikan. Dalam konteks ini, gurumempunyai peranan yang sangat besar dan strategis, karena gurulah yangberada di barisan paling depan dalam pelaksanaan pendidikan. Gurulangsung berhadapan dengan peserta didik dalam kegiatan pembelajaranyang di dalamnya mencakup kegiatan pentransferan ilmu pengetahuan danteknologi serta penanaman nilai-nilai positif melalui bimbingan dan jugatauladan. Guru harus menjadi contoh yang baik.
Baikdalam konteks pribadi maupun dalam lingkungan sosial. Guru harus menjadi insan yang memiliki integritas sehingga dapat diterima dilingkungannya. Guru diposisikan sebagai seorang motivator. Setiap gerak, perbuatan danperkataan seorang guru harus berkaitan dengan upaya menumbuhkanminat dan interes $t$ siswa terhadap sesuatu yang baru dan baik.Seorang guru merupakan sosok yang memiliki kepribadian yang kuat.Guru secara terus-menerus harus selalu memberikan sumbangan yangpositif 
kepada dunia pendidikan. Guru tidak hanya memberikan suatupengawasan, tetapi juga selalu memantau perjalanan akademik dan psikis siswa.

Beberapa ciri khas dari pembelajaran tematik antara lain: (1) Pengalaman dan kegiatan belajar sangat relevan dengan tingkat perkembangan dan kebutuhan anak usia sekolah dasar; (2) Kegiatankegiatan yang dipilih dalam pelaksanaan pembelajaran tematik bertolak dari minat dan kebutuhan siswa; (3) Kegiatan belajar akan lebih bermakna dan berkesan bagi siswa sehingga hasil belajar dapat bertahan lebih lama; (4) Membantu mengembangkan keterampilan berpikir siswa; (5) Menyajikan kegiatan belajar yang bersifat pragmatis sesuai dengan permasalahan yang sering ditemui siswa dalam lingkungannya; dan (6) Mengembangkan keterampilan sosial siswa, seperti kerjasama, toleransi, komunikasi, dan tanggap terhadap gagasan orang lain (http://akhmadsudrajat.wordpress.co

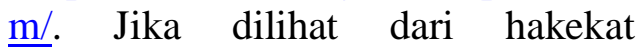
pembelajaran Tematik sesuai penjelasan di atas akan sangat cocok diterapkan dengan pendekatan sainstifik. Pendekatan saintifik/ilmiah, selain dapat menjadikan siswa lebih aktif dalam mengkonstruksi pengetahuan dan keterampilannya, juga dapat mendorong siswa untuk melakukan penyelidikan guna menemukan fakta-fakta dari suatu fenomena atau kejadian. Artinya, dalam proses pembelajaran, siswa dibelajarkan dan dibiasakan untuk menemukan kebenaran ilmiah, bukan diajak untuk beropini dengan pengetahuan mengambang dalam melihat suatu fenomena. Mereka dilatih untuk mampu berfikir logis, runut dan sistematis, dengan menggunakan kapasistas berfikir tingkat tinggi.

Dengan memahami semua cuplikan yang sudah disampaikan maka kondisi yang diharapkan terjadi dalam pembelajaran Tematik di Sekolah Dasar sudah dapat dipahami. Dengan kondisi tersebut, apabila guru betul melakukannya dengan baik, tentu saja akan terpenuhi kondisi yang diharapkan dalam pembelajaran.

Oleh karenanya peneliti mencoba untuk menerapkan model pembelajaran Tematik dengan bantuan metode bercakap-cakap dan bercerita dalam penelitian ini dengan maksud untuk mengatasi permasalahan masih rendahnya prestasi belajar bahasa Indonesia siswa kelas III semester I SD Negeri 22 Dangin Puri Dari hasil observasi sementara didapat data awal kemampuan anak menunjukkan bahwa 10 anak dari yang diteliti memperoleh nilai 60,0 sedangkan 3 anak memperoleh nilai 65,0 Hal ini masih jauh dari harapan yang ditetapkan dalam Standar Minimal Keberhasilan Pembelajaran. Karena itu penelitian ini penting untuk dilaksanakan sebagai upaya memecahkan masalah yang ada.

\section{METODE}

Penelitian ini dilaksanakan di jln Kapten Japa Kecamatan Denpasar Timur, penelitian yang dilakukan termasuk penelitian tindakan.Oleh karenanya, rancangan yang khusus untuk sebuah penelitian tindakan sangat diperlukan.Penelitian tindakan didasarkan pada filosofi bahwa setiap manusia tidak suka atas halhal yang statis, tetapi selalu menginginkan sesuatu yang lebih baik.Peningkatan diri untuk hal yang 
lebih baik ini dilakukan terus menerus sampai tujuan tercapai (Suharsimi Arikunto, Suhardjono, Supardi, 2006: 67). Prosedur penelitian sebagai berikut:

- Tindakan daur I: mulai dari definisi masalah, berlanjut ke assessment yang disiapkan, berlanjut ke rumusan hipotesis, berlanjut ke pengembangan untuk tindakan I, lalu implementasi tindakan, evaluasi tindakan berlanjut ke penerapan selanjutnya.

- Tindakan daur II: mulai dari menentukan kembali masalah yang ada, berlanjut ke assessment yang disiapkan, terus ke pemikiran terhadap munculnya hipotesis yang baru, perbaikan tindakan pada rencana ke 2, pelaksanaan tindakan, evaluasi terhadap semua pelaksanaan dan penerapan

Subjek penelitian ini adalah semua siswa kelas III semester I tahun Pelajaran 2017/2018 SD Negeri 22 Dangin Puri. Yang menjadi objek penelitian ini adalah peningkatan prestasi belajar Bahasa Indonesia siswa kelas III Semester I tahun Pelajaran 2017/2018 SD Negeri 22 Dangin Puri setelah diterapkan model Tematik dalam proses pembelajaran. Penelitian ini dilakukan dari bulan Juli sampai bulan Nopember 2017, untuk mengumpulkan data penelitian ini adalah tes prestasi belajar. Metode yang digunakan untuk menganalisis data hasil penelitian ini adalah metode deskriptif. Data kuantitatif dianalisis dengan mencari mean, median, modus, standar deviasi, membuat interval kelas dan melakukan penyajian dalam bentuk tabel dan grafik. Instrumen yang digunakan untuk menilai prestasi belajar siswa kelas III adalah tes.
Tes ini terdiri dari 5 soal dengan bentuk tes adalah isian. Dalam penelitian ini diusulkan tingkat keberhasilan per siklus yaitu pada prestasi belajar siswa diharapkan pada siklus I mencapai rata-rata 70,0 dengan ketuntasan belajar minimal $80 \%$ dan pada siklus II mencapai nilai rata-rata 75,0 atau lebih dengan ketuntasan belajar minimal $80 \%$.

\section{KAJIAN PUSTAKA Model Pembelajaran Tematik}

Salah satunya bahwa pengembangan potensi peserta didik sangat penting dalam upaya untuk dapat memajukan bangsa.Kemajuan bangsa Indonesia tentu banyak ditentukan oleh pendidikan yang mampu mengembangkan potensi siswa.Pengembangan potensi peserta didik yang dimaksud bertujuan agar kelak peserta didik mampu menghadapi dan memecahkan problema-problema kehidupan yang dihadapinya.Upaya-upaya yang bisa dilakukan untuk mencapai pemenuhan hal-hal di atas tidaklah gampang karena hal tersebut mesti dimulai sejak anak-anak berusia dini baik pada saat mereka masih di Taman Kanak-Kanak maupun pada saat mereka belajar di Sekolah Dasar. Pendidikan Anak Usia Dini (PAUD) adalah jenjang pendidikan sebelum jenjang pendidikan dasar yang merupakan suatu upaya pembinaan yang ditujukan bagi anak sejak lahir sampai usia enam tahun yang dilakukan melalui pemberian rangsangan pendidikan untuk membantu pertumbuhan dan perkembangan jasmani dan rohani anak agar memiliki kesiapan dalam memasuki pendidikan lebih lanjut, yang diselenggarakan pada jalur formal, nonformal dan informal (Depdiknas, 2006: 2). Anak-anak 
usia dini masih melihat sesuatu sebagai satu kesatuan yang utuh (holistik). Peserta didik yang berada pada Sekolah Dasar kelas satu, dua dan tiga berada pada rentangan usia dini (Depdiknas, 2010: 3).

Menurut Prabowo, 2000 (dalam Trianto, 2010: 95) sintaks pembelajaran terpadu secara khusus dapat dibuat tersendiri berupa langkah-langkah baru dengan ada sedikit perbedaan yakni sebagai berikut: Pertama, tahap perencanaan. Pada tahap ini hal-hal yang dilakukan antara lain: 1) menentukan kompetensi dasar dan 2) menentukan indikator dan hasil belajar.

Kedua, tahap pelaksanaan yang meliputi sub-tahap: I) Proses pembelajaran oleh guru. Adapun langkah yang ditempuh guru, antara lain: 1) menyampaikan konsep pendukung yang harus dikuasai siswa; 2) menyampaikan konsepkonsep pokok yang akan dikuasai oleh siswa; 3) menyampaikan keterampilan, proses yang akan dikembangkan; 4) menyampaikan alat dan bahan yang dibutuhkan dan 5) menyampaikan pertanyaan kunci. II) Tahap manajemen, yang meliputi langkah-langkah: 1) pengelolaan kelas, dimana kelas dibagi dalam beberapa kelompok; 2) kegiatan proses; 3) kegiatan pencatatan data; dan 4) diskusi.

Ketiga, evaluasi yang meliputi: 1) Evaluasi proses. Adapun hal-hal yang menjadi perhatian dalam evaluasi proses terdiri dari: (a) ketepatan hasil pengamatan, (b) ketepatan penyusunan alat dan bahan dan (c) ketepatan menganalisa data. 2) Evaluasi hasil yaitu penguasaan konsep-konsep sesuai indikator yang telah ditetapkan. 3) Evaluasi psikomotorik, yaitu penguasaan penggunaan alat ukur. Sedangkan Hadisubroto, 2000 (dalam Trianto, 2010: 95) menyatakan bahwa dalam merancang pembelajaran terpadu sedikitnya ada empat hal yang perlu diperhatikan sebagai berikut: (1) menentukan tujuan, (2) menentukan Materi/media, (3) menyusun skenario KBM, (4) menentukan evaluasi.

\section{Model Pembelajaran Terpadu}

Depdiknas (2009) menyatakan model pembelajaran terpadu terdiri atas berbagai model, antara lain:

\section{1) Fragmented}

Diibaratkan sebagai periskop, satu arah, terfokus langsung pada satu bidang mata pelajaran saja. Merupakan suatu metode pembelajaran yang sangat "tradisional" sangat steril dan tidak saling terkait karena terkotak-kotak.

2) Connected

Diibaratkan sebagai opera glass, sangat rinci menelaah satu bidang mata pelajaran dengan seluk beluknya. Merupakan model pembelajaran yang dirancang sedemikian rupa sehingga menjadi sistematika dan saling berhubungan. Mulai dari topik ke konsep, dan dari semester ke semester berikutnya.

3) Nested

Diibaratkan sebagai kaca tiga dimensi beragam dimensi dari suatu tema/unit. Guru sudah memiliki target untuk dapat mengaitkan antara kecakapan sosial-berpikir dan sebuah materi kecakapan khusus.

4) Sequenced 
Diibaratkan sebagai kacamata materi ajar dibingkai dengan konsep yang sama dan saling terkait. Tema-tema antara dua bidang mata pelajaran dirancang sedemikian rupa sehingga sejajar.

5) Shared

Diibaratkan sebagai binokular dua bidang mata pelajaran saling berbagi dan tumpang tindih konsep dan kecakapannya.

6) Webbed

Diibaratkan sebagai teleskopmemiliki konstelasi yang luas dengan menggunakan tema yang mencakup berbagai unsur. Sebuah tema mesti subur dan kaya sehingga cakupannya saling terkait antarkonsep, topik dan berbagai gagasan lainnya.

7) Threaded

Diibaratkan sebagai kaca pembesar/suryakanta- dengan gagasan yang membesar sehingga jelas pada semua bidang mata pelajaran. Pendekatan metakurikular yang dilakukan melalui keterkaitan berbagai ketrampilan seperti ketrampilan berpikir, ketrampilan bersosialisasi, kecerdasan jamak, teknologi, dan berbagai disiplin ilmu lainnya.

8) Integrated

Diibaratkan sebagai kaleidoskop sebuah pola dan rancangan baru dengan pendekatan lintas mata pelajaran.

9) Immersed

Diibaratkan sebagai mikroskop- bereksplorasi dengan materi sesuai minat
http://ejournal.ihdn.ac.id/index.php/AW

dan keahlian siswa, sehingga mereka dapat menyatu dan tercelup dengan diri mereka sendiri sebagai pemelajar.

10) Networked

Diibaratkan sebagai perismamenciptakan beragam dimensi yang terarah dan terfokus. Siswa sebagai pemelajar akan menyaring dan mengaitkan semua mata pelajaran dengan cara profesional.

\section{Metode Bercakap-cakap dan Bercerita}

Winda Gunarti (2010: 5.3 - 5.7) menjelaskan bahwa metode bercerita adalah metode yang dilakukan seseorang untuk menyampaikan suatu pesan, informasi atau sebuah dongeng belaka yang bisa dilakukan secara lisan atau tertulis. Cara permainan cerita tersebut dapat dilakukan dengan menggunakan alat peraga atau tanpa alat peraga. Tujuan metode bercerita adalah mengembangkan kemampuan berbahasa, berfikir dengan bercerita, menanamkan pesan-pesan moral, kepekaan sosial emosional, melatih daya ingat, mengembangkan potensi kreatif melalui keragaman ide cerita. Bentuk-bentuknya adalah tanpa alat peraga dan dengan alat peraga.

H. Martinis Yamin dan Jamilah Sabri Sanan (2013: 2) menulis bahwa secara alamian, perkembangan anak berbeda-beda, baik intelejensi, bakat, minat, kreativitas, kematangan emosi, kepribadian, kemandirian, jasmani, dan sosialnya. Selanjutnya dijelaskan bahwa Abraham Maslow telah menjelaskan tentang hirarki dari kebutuhan dasar manusia karena setiap individu itu berbeda, baik dilihat dari jenis kelamin, 
tempramen, ketertarikan, gaya belajar, pengalaman hidup, budaya, kebutuhannya.

\section{Prestasi Belajar}

Prestasi belajar merupakan hasil dari proses pembelajaran yang dilakukan siswa di sekolah sebagaimana biasa dilaporkan pada wali kelas, murid dan orang tua siswa setiap akhir semester atau akhir tahun ajaran dalam bentuk buku Raport.

Prestasi belajar mempunyai arti dan manfaat yang sangat penting bagi anak didik, pendidik, orang tua/wali murid dan sekolah, karena nilai atau angka yang diberikan merupakan manifestasi dari prestasi belajar siswa dan berguna dalam pengambilan keputusan atau kebijakan terhadap siswa yang bersangkutan maupun sekolah.Prestasi belajar merupakan kemampuan siswa yang dapat diukur, berupa pengetahuan, sikap dan keterampilan yang dicapai siswa dalam kegiatan belajar mengajar.

Sardiman (1988:

menyatakan prestasi belajar sangat vital dalam dunia pendidikan, mengingat prestasi belajar itu dapat berperan sebagai hasil penilaian dan sebagai alat motivasi.Adapun peran sebagai hasil penilaian dan sebagai alat motivasi diuraikan seperti berikut.

Dari uraian di atas, dapat disimpulkan bahwa prestasi belajar adalah hasil yang dicapai siswa setelah melakukan kegiatan belajar yang berbentuk angka sebagai simbol dari ketuntasan belajar.Prestasi belajar ini sangat dipengaruhi oleh factor luar yaitu guru dan metode.Hal inilah yang menjadi titik perhatian peneliti di lapangan.

\section{Pembelajaran Bahasa Indonesia}

- Pengertian Pembelajaran

Bahasa Indonesia Belajar merupakan tindakan dan perilaku siswa yang kompleks..

- Belajar adalah suatu proses usaha yang dilakukan individu untuk memperoleh perubahan tingkah laku secara keseluruhan sebagai hasil pengalaman individu dalam interaksi dengan lingkungannya. Sedangkan, pembelajaran yakni bagaimana membelajarkan siswa atau bagaimana membuat siswa dapat belajar dengan mudah dan terdorong oleh kemauannya sendiri untuk mempelajari apa yang teraktualisasikan dalam kurikulum sebagai kebutuhan peserta didik.

Bahasa memegang peranan penting dalam kehidupan kita. Hal iniharuslah kita sadari benar-benar, apalagi bagi para guru bahasa pada khususnya dan bagi para guru bidang studi pada umumnya. Dalam tugasnya sehari-hari para guru bahasa harus memahami benar-benar bahwa tujuan akhir pembelajaran bahasa ialah agar para siswa terampil berbahasa; yaitu terampil menyimak, berbicara, membaca, dan menulis. Dengan perkataan lain, agar para siswa mempunyai kompetensi bahasa (language competence) yang baik. Apabila seseorang mempunyai kompetensi bahasa yang baik, maka siswa diharapkan dapat berkomunikasi dengan orang lain secara baik dan lancar, baik secara lisan maupun tulisan. Siswa juga diharapkan menjadi penyimak dan pembicara yang baik, menjadi 
pembaca yang komprehensif serta penulis yang terampil dalam kehidupan sehari-hari. Untuk mencapai tujuan ini, maka para guru berupaya sekuat daya harus menggunakan bahasa dengan baik dan benar, agar siswa dapat meneladaninya.8 Suatu kenyataan bahwa manusia menggunakan bahasa sebagai sarana komunikasi vital dalam hidup ini. Bahasa adalah milik manusia. Bahasa adalah salah satu ciri pembeda utama kita sebagai umat manusia dengan makhluk hidup lainnya di dunia ini. Setiap anggota masyarakat terlibat dalam komunikasi linguistik; di satu pihak dia bertindak sebagai pembicara dan di pihak lain sebagai penyimak. Dalam komunikasi yang lancar, proses perubahan dari pembicara menjadi penyimak maupun dari penyimak menjadi pembicara terjadi begitu cepat, terasa sebagai suatu peristiwa biasa dan wajar.

Oleh sebab itu, pengertian bahasa ditinjau dari dua segi, yakni segi teknis dan segi praktis.

a. Pengertian bahasa secara teknis adalah seperangkat ujaran yang bermakna, yang dihasikan dari alat ucap manusia.

b. Secara praktis, bahasa merupakan alat komunikasi antara anggota masyarakat yang berupa sistem lambang bunyi yang bermakna, yang dihasilkan dari alat ucap manusia. Dari pengertian secara praktis ini dapat kita ketahui bahwa bahasa dalam hal ini mempunyai dua aspek, yaitu aspek sistem (lambang) bunyi dan aspek makna. Bahasa disebut sistem bunyi atau sistem lambang bunyi karena bunyi-bunyi bahasa yang kita dengar atau kita ucapkan itu sebenarnya bersistem atau memiliki keteraturan. Dalam hal ini, istilah sistem bunyi hanya terdapat di dalam bahasa lisan, sedangkan di dalam bahasa tulis bahasa sistem bunyi itu digambarkan dengan lambanglambang tertentu yang disebut huruf. Dengan demikian, bahasa selain dapat disebut sistem bunyi, juga disebut sistem lambang.

c. Dari pemaparan tersebut di atas, maka dapat disimpulkan bahwa pembelajaran bahasa Indonesia adalah suatu proses perjalanan panjang yang dilalui oleh setiap siswa dalam mempelajari bahasa Indonesia atau bahasa kedua setelah bahasa Ibu. Adapun kompetensi dalam pembelajaran bahasa Indonesia meliputi menyimak, berbicara, membaca, dan menulis.

\section{Fungsi dan Tujuan Pembelajaran Bahasa Indonesia}

Di dalam kedudukannya sebagai bahasa nasional, bahasa Indonesia berfungsi yakni sebagai lambang kebanggaan kebangsaan, lambingidentitas nasional, alat pemersatu, serta alat komunikasi antardaerah dan antarkebudayaan.

Berikut ini merupakan fungsi pembelajaran Bahasa Indonesia, antara lain:

a. Untuk meningkatkan produktivitas pendidikan, dengan jalan mempercepat laju belajar dan membantu guru untuk menggunakan waktunya secara lebih baik, dan mengurangi beban guru dalam menyajikan informasi, sehingga dapat lebih banyak membina dan 
mengembangkan gairah belajar siswa.

b. Memberikan kemungkinan pendidikan yang sifatnya lebih individual, dengan jalan mengurangi kontrol guru yang kaku dan tradisional, serta memberikan kesempatan bagi siswa untuk berkembang sesuai dengan kemampuannya.

c. Memberikan dasar yang lebih ilmiah terhadap pengajaran, dengan jalan perencanaan program pendidikan yang lebih sistematis, serta pengembangan bahan pengajaran yang dilandasi oleh penelitian perilaku.

d. Lebih memantapkan pengajaran, dengan jalan menongkatkan kemampuan manusia denagan berbagai media komunikasi, serta penyajian informasi dan data secara lebih konkrit.

e. Memungkinkan belajar secara seketika, karena dapat mengurangi jurang pemisah antara pelajaran yang bersifat verbal dan abstrak dengan realitas yang sifatnya konkrit, serta memberikan pengetahuan yang sifatnya langsung.

f. Memungkinkan penyajian pendidikan yang lebih luas, terutama dengan alat media massa.

\section{Tujuan pembelajaran Bahasa Indonesia, yaitu:}

a. Berkomunikasi secara efektif dan efesien sesuai dengan etika yang berlaku, baik secara lisan maupun tulis.

b. Menghargai dan bangga menggunakan Bahasa Indonesia sebagai bahasa persatuan dan bahasa negara. c. Memahami bahasa indonesia serta menggunakan dengan tepat dan kreatif untuk berbagai tujuan.

d. Menggunakan bahasa indonesia untuk meningkatkan kemampuan intelektual, serta kematangan emosional dan sosial.

e. Menikmati dan memanfaatkan karya sastra untuk memperluaswawasan, memperluas budi pekerti, meningkatkan pengetahuan maupun kemampuan berbahasa serta bersastra sebagai khasanah budaya dan juga intelektual manusia Indonesia.

\section{Manfaat Pembelajaran Bahasa Indonesia di SD}

Pembelajaran bahasa Indonesia memiliki fungsi sebagai berikut: (1). Sarana pembinaan persatuan dan kesatuan bangsa (2). Sarana peningkatan pengetahuan dan keterampilan dalam rangka pelestarian dan pengembangan budaya (3). Sarana peningkatan pengetahuan dan keterampilan untuk meraih dan mengembangkan ilmu pengetahuan, teknologi, dan seni. (4). Sarana penyebarluasan pemakaian bahasa Indonesia yang baik untuk berbagai keperluan menyangkut berbagai masalah, (5). Sarana pengembangan penalaran, dan (6). Sarana pemahaman beragam budaya Indonesia melalui khazanah kesusasteraan Indonesia (Kurikulum KTSP, 2006).

$$
\text { Kegiatan pembelajaran }
$$

bahasa Indonesia di sekolah dasar diharapkan mampu mengembangkan dan mengarahkan siswa dengan segala potensi yang dimilikinya secara optimal, yaitu guru dapat mendorong siswa untuk berpikir secara kritis. 
Keberhasilan pelaksanaan proses pembelajaran di kelas, terkait dengan kemampuan guru, baik sebagai perancang pembelajaran maupun sebagai pelaksana di lapangan. Selain itu, guru dituntut mampu melakukan pembaharuan khususnya dalam pembelajaran bahasa Indonesia, yaitu dengan merancang pembelajaran berdasarkan pengalaman belajar siswa sehingga menghasilkan pembelajaran yang bermakna.

\section{HASIL PENELITIAN DAN PEMBAHASAN \\ Hasil Penelitian}

Pada bagian ini, akan dipaparkan data yang diperoleh dari penelitian tindakan ini secara rinci berdasarkan penelitian yang dilakukan di SD Negeri 22 Dangin Puri Kecamatan Denpasar Timur . Sebelum menyampaikan hasil-hasil penelitian ada baiknya dilihat dahulu pendapat para ahli pendidikan berikut: dalam menyampaikan hasil penelitian dan pembahasan

\section{Refleksi Siklus I}

Refleksi merupakan kajian secara menyeluruh tindakan yang telah dilakukan berdasarkan data yang telah terkumpul, kemudian dilakukan evaluasi guna menyempurnakan tindakan.Refleksi menyangkut analisis, sintesis, dan penilaian terhadap hasil pengamatan atas tindakan yang dilakukan (Hopkin, 1993 dalam Suharsimi Arikunto, Suhardjono, Supardi, 2006: 80). Analisis kuantitatif Prestasi belajar siswa siklus I

ARata-rata (mean) hasilnya 66,47

b) Median (titik tengahnya) dicari dengan mengurut data/nilai siswa dari yang terkecil sampai terbesar. Setelah diurut apabila jumlah data
http://ejournal.ihdn.ac.id/index.php/AW

ganjil maka mediannya adalah data yang ditengah. kalau jumlahnya genap maka dua data yang di tengah dijumlahkan dibagi 2 (dua). Untuk median yang diperoleh dari data siklus I dengan menggunakan cara tersebut adalah: 65 .

c) Modus (angka yang paling banyak/paling sering muncul) setelah diasccending/diurut angka tersebut adalah: 70. Untuk persiapan penyajian dalam bentuk grafik maka hal-hal berikut dihitung terlebih dahulu. Banyak kelas (K) diperoleh hasil 5,29 dibulatkan menjadi 5 . Rentang kelas (r) diperoleh 25, dan panjang kelas $=5$

\section{Siklus II}

\section{Observasi/Pengamatan II}

Hasil pengamatan pada siklus II penelitian sampaikan pada table

\section{Refleksi Siklus II}

Analisis kuantitatif Prestasi belajar siswa siklus II

1. Rata-rata (mean) hasilnya 77,76

2. Median (titik tengahnya) dicari dengan mengurut data/nilai siswa dari yang terkecil sampai terbesar. Setelah diurut apabila jumlah data ganjil maka mediannya adalah data yang ditengah. Kalau jumlahnya genap maka dua data yang di tengah dijumlahkan dibagi 2 (dua). Untuk median yang diperoleh dari data siklus I engan menggunakan cara tersebut adalah: 75 .

3. Modus (angka yang paling banyak/paling sering muncul) setelah diasccending/diurut. Angka tersebut adalah: 80.Untuk persiapan penyajian dalam bentuk grafik maka halhal berikut dihitung terlebih 
dahulu. BAnyak kelas $=5,29$ dibulatkan menadi 5. Rentang kelas $(r)=20$, dan panjang kelas $=4$.

\section{PEMBAHASAN}

Data awal yang diperoleh dengan rata-rata 64,72 menunjukkan bahwa kemampuan anak kelas III dalam mata pelajaran Bahasa Indonesia masih sangat rendah mengingat kriteria ketuntasan belajar siswa untuk mata pelajaran Bahasa Indonesia ini di SD Negeri 22 Dangin Puri adalah 42,85\% Dengan nilai yang sangat rendah seperti itu maka peneliti mengupayakan untuk dapat meningkatkan prestasi belajar anak menggunakan metode bercakap-cakap dan bercerita Akhirnya dengan penerapan metode bercakap- cakap dan bercerita yang benar sesuai teori yang ada, peningkatan rata-rata prestasi belajar anak pada siklus I dapat diupayakan dan mencapai rata-rata.66,47 Namun rata-rata tersebut belum maksimal karena hanya 10 siswa memperoleh nilai di atas KKM sedangkan yang lainnya belum mencapai KKM. Sedangkan prosentase ketuntasan belajar mereka baru mencapai $47,61 \%$. Hal tersebut terjadi akibat penggunaan metodebercakap-cakap dan bercerita belum maksimal dapat dilakukan disebabkan penerapan metode tersebut baru dicobakan sehingga guru masih belum mampu melaksanakannya sesua alur teori yang benar.

Pada siklus ke II perbaikan prestasi belajar siswa diupayakan lebih maksimal dengan peneliti membuat perencanaan yang lebih baik, menggunakan alur dan teori dari metode bercakap-cakap dan bercerita dengan benar dan lebih maksimal.Peneliti giat memotivasi siswa agar giat belajar, memberi arahan-arahan, menuntun mereka untuk mampu menguasai materi pelajaran pada mata pelajaran Bahasa Indonesia lebih optimal. Akhirnya dengan semua upaya tersebut peneliti mampu meningkatkan prestasi belajar siswa pada siklus II menjadi rata-rata 77,76 Upaya-upaya yang maksimal tersebut menuntun kepada penelitian bahwa metode Bercakap-cakap dan bercerita mampu meningkatkan prestasi belajar siswa.

\section{SIMPULAN}

Berdasarkan hasil penelitian sebagaimana terurai pada Bab IV, kiranya untuk menandai akhir dari penulisan laporan ini dapat ditarik kesimpulan penting sebagai jawaban atas masalah-masalah penelitian yang telah dikemukakan di awal penelitian, sebagai berikut:Penerapan metode bercakap-cakap dan bercerita terbukti bisa meningkatkan prestasi hasil belajar Bahasa Indonesia dan ketuntasan belajar siswa kelas III Semester I SD Negeri 22 Dangin Puri Tahun Pelajaran 2007/2008 terhadap materi pokok pembelajaran 'Bahasa Indonesia".

Peningkatannya terhadap prestasi hasil belajar Bahasa Indonesia siswa kelas III yang semula dari data awal diperoleh hasil 64,72 yang menunjukkan bahwa kemampuan anak masih tergolong rendah. Setelah tindakan pada siklus I hasil tersebut meningkat menjadi 66,47. Setelah pelaksanaan siklus II terjadi peningkatan dari 66,47 pada siklus pertama meningkat menjadi 77,76 pada siklus kedua, suatu peningkatan yang boleh dibilang cukup signifikan. Sementara peningkatannya terhadap ketuntasan belajar siswa sangat signifikan, dari 
$42,85 \%$ yang belum tuntas pada data awal menjadi $47,61 \%$ siklus pertama dan menjadi $100 \%$ pada siklus kedua. Itu artinya, penerapan metode bercakap -cakap dan bercerita sampai akhir siklus kedua terbukti berhasil menuntaskan embelajaran $100 \%$ dari 21 siswa subyek penelitian.

\section{DAFTAR PUSTAKA}

Arikunto, Suharsimi; Suhardjono; Supardi. 2006. Penelitian Tindakan Kelas. Jakarta: PT Bumi Aksara.

Badan Standar Nasional Pendidikan. 2007. Peraturan Menteri Pendidikan Nasional Republik Indonesia Nomor 41 Tahun 2007. Jakarta: BSNP.

Daryanto. $1999 . \quad$ Evaluasi Pendidikan. Rineka Cipta: Jakarta.

Depdiknas, 2003c.Sistem Penilaian Kelas SD, SMP, SMA dan SMK. Dirjen Dikdasmen Tendik.

Depdiknas. 2008. Pengolahan dan Analisis Data Penelitian. Jakarta: Direktorat Tenaga Kependidikan Dirjen PMPTK.

Depdiknas. 2010. Pedoman Pengembangan Program Pembelajaran di Taman KanakKanak. Jakarta: Direktorat Pembinaan TK dan SD, Dirjen Pendidikan Dasar dan Menengah.

Depdiknas. 2010. Peraturan Menteri Pendidikan Nasional Republik Indonesia Nomor 58 Tahun 2009 tentang Standar Pendidikan Anak Usia Dini (PAUD). Jakarta: Direktorat
http://ejournal.ihdn.ac.id/index.php/AW

Jendral Manajemen Pendidikan

Dasar dan Menengah Direktorat

Pembinaan TK dan SD.

Depdiknas. 2010. Perkembangan Anak Usia Dini. Jakarta: Direktorat Pembinaan TK dan SD, Dirjen Pendidikan Dasar dan Menengah.

Dimyati dan Mudjiono. 2001. Belajar dan Pembelajaran. Jakarta: Dirjen Dikti.

Djamarah, Syaful Bahri. 2002. Prestasi Belajar dan Kompetensi Guru. Surabaya: Usaha Nasional.

Gunarti, Winda, dkk. 2010. Metode Pengembangan Prilaku dan Kemampuan Dasar Anak Usia Dini. Jakarta: Universitas Terbuka.

Nana Sudjana. 2000. http://www.scribd.com/doc/ 9037208/.

Purwanto, Ngalim. 1997. Psikologi Pendidikan. Bandung: Rosdakarya.

Sahertian, Piet A \& Aleida Sahertian.1992. Supervisi Pendidikan dalam Rangka Program Inservice Education. Jakarta: Rineka Cipta.

Sardiman, A.M. 1988. Interaksi dan Motivasi Belajar-Mengajar Pedoman bagi Guru dan Calon Guru. Jakarta: Rajawali Pers.

Slameto. 2003. Belajar dan Faktorfaktor yang Mempengaruhinya. Jakarta: Rineka Cipta.

Slavin, Robert E. 1995.Cooperative Learning : Theory, Research, and Practice. Boston: Allyn and Bacon 